\title{
Bovine manure as a dispersing agent for weeds and invasive alien plants
}

\author{
Esterco bovino como agente dispersor de plantas daninhas e exóticas invasoras \\ Estiércol bovino como agente dispersante de malezas y plantas no autóctonas
}

Received: 06/04/2021 | Reviewed: 06/14/2021 | Accept: 06/21/2021 | Published: 07/05/2021

\author{
Diego de Andrade Mendonça \\ ORCID: https://orcid.org/0000-0002-0934-1077 \\ Universidade Federal de Sergipe,Brazil \\ E-mail: diecoecobio@outolook.com \\ Daniel Oliveira Reis \\ ORCID: https://orcid.org/0000-0002-3969-4842 \\ Universidade Federal de Sergipe,Brazil \\ E-mail: daniel.olire@gmail.com \\ Josias Gomes Junior \\ ORCID: https://orcid.org/0000-0002-3498-0604 \\ Universidade Federal de Sergipe,Brazil \\ E-mail: josiasjrbio@outlook.com \\ Juliano Ricardo Fabricante \\ ORCID: https://orcid.org/0000-0003-4767-7302 \\ Universidade Federal de Sergipe,Brazil \\ E-mail: julianofabricante@ @otmail.com
}

\begin{abstract}
Fertilization is the act of adding fertilizers to the soil in order to provide essential nutrients for the development of cultivated plants. However, the use of bovine manure can act as a source of weed propagules, including non-native species. Due to the importance and lack of research on the topic, the objective of the present study was to evaluate the seed bank present in bovine manure used by farmers in the municipality of Itabaiana, SE. For that, samples of bovine manure were collected in 10 rural properties in the municipality of Itabaiana, SE. The evaluation of the seed bank was carried out by accounting for emerged seedlings. Usual phytosociological indices were calculated for each species. Altogether 35 species were sampled, of which 28 native and seven non-native. The native species with the highest importance value was Euphorbia hirta, as it has the highest density $\left(\mathrm{AD}=1122\right.$ ind. $\left.\mathrm{m}^{-2}\right)$ and is present in 28 sample units. The non-native species with the highest importance value was Eleusine indica, because it has the third highest density $\left(\mathrm{AD}=171.2 \mathrm{~m}^{2}\right)$ and is present in 21 sample units. The obtained results reveal that bovine manure has a high number of weed, which is quite worrying, as they are species that generate important environmental and economic impacts.
\end{abstract}

Keywords: Seed bank; Economic loss; Environmental impact.

\section{Resumo}

A fertilização é o ato de adicionar fertilizantes ao solo com o objetivo de fornecer nutrientes essenciais para o desenvolvimento das plantas cultivadas. No entanto, o uso de esterco bovino pode atuar como fonte de propágulos de plantas daninhas, incluindo espécies não nativas. Dada a importância e a escassez de pesquisas sobre o tema, o objetivo do presente estudo foi avaliar o banco de sementes presente em esterco bovino utilizado por produtores rurais do município de Itabaiana, SE. Para tanto, foram coletadas amostras de esterco bovino em 10 propriedades rurais do município de Itabaiana, SE. A avaliação do banco de sementes foi realizada por meio da contabilização de plantas emergidas. Índices fitossociológicos usuais foram calculados para cada espécie. Ao todo foram amostradas 35 espécies, sendo 28 nativas e sete não nativas. A espécie nativa com maior valor de importância foi Euphorbia hirta, por apresentar a maior densidade ( $\mathrm{DA}=1122$ ind. $\left.\mathrm{m}^{-2}\right)$ e estar presente em 28 unidades amostrais. A espécie não nativa com maior valor de importância foi Eleusine indica, por apresentar a terceira maior densidade (DA $=171,2 \mathrm{~m}^{2}$ ) e estar presente em 21 unidades amostrais. Os resultados obtidos revelam que o esterco bovino possui um elevado número de plantas daninhas, o que é bastante preocupante, pois são espécies que geram importantes impactos ambientais e econômicos.

Palavras-chave: Banco de sementes; Perda econômica; Impacto ambiental.

\section{Resumen}

La fertilización es el acto de agregar fertilizantes al suelo con el fin de proporcionar los nutrientes esenciales para el desarrollo de las plantas cultivadas. Sin embargo, el uso de estiércol bovino puede actuar como fuente de propágulos de malezas, incluidas las especies no autóctonas. Debido a la importancia y falta de investigación sobre el tema, el objetivo del presente estudio fue evaluar el banco de semillas presente en el estiércol bovino utilizado por los agricultores del municipio de Itabaiana, SE. Para ello, se recolectaron muestras de estiércol bovino en 10 predios rurales del municipio 
de Itabaiana, SE. La evaluación del banco de semillas se llevó a cabo contabilizando las plántulas emergidas. Se calcularon los índices fitosociológicos habituales para cada especie. En total se muestrearon 35 especies, de las cuales 28 nativas y siete no nativas. La especie nativa con mayor valor de importancia fue Euphorbia hirta, ya que tiene la mayor densidad $\left(\mathrm{DA}=1122\right.$ ind. $\left.\mathrm{m}^{-2}\right)$ y está presente en 28 unidades de muestra. La especie no autóctona con mayor valor de importancia fue Eleusine indica, porque tiene la tercera densidad más alta $\left(\mathrm{DA}=171,2 \mathrm{~m}^{2}\right)$ y está presente en 21 unidades de muestra. Los resultados obtenidos revelan que el estiércol bovino tiene un alto número de malezas, lo cual es bastante preocupante, ya que son especies que generan importantes impactos ambientales y económicos.

Palabras clave: Banco de semillas; Pérdida económica; Impacto medioambiental.

\section{Introduction}

Fertilization is the act of adding fertilizers to the soil in order to provide essential nutrients for the development of cultivated plants (Brasil et al., 1999). They can be of two types: mineral or organic. The first type is in mineral form, that is, it is already ready to be used by plants. The second type, on the other hand, must first go through the mineralization process (Embrapa, 2021).

The use of organic fertilizers, such as manure, has advantages over minerals, because in addition to providing proteins, enzymes, vitamins, natural antibiotics, alkaloids and nutrients for plants (Finatto et al., 2013), they also favor the maintenance of edaphic fauna (Barros et al., 2002) and improve the soil structure by increasing its aeration and water retention capacity (Trigueiro and Guerrini, 2003). However, manure can act as a source of weed propagules (Pitelli, 1987), which can generate a substantial impact on crops.

Weeds are any plant that interferes in the interests of man and the environment (Pitelli, 2015). Because they need the same resources as cultivated plants, they compete with them for nutrients, water and light (Pitelli, 1987), many are host of pathogens (Sales-junior et al., 2012), causing food poisoning in animals (Brighenti et al., 2017), release allelochemicals into the environment (Cremonez, et al., 2013) and decrease the quality of pastures (Mascarenhas et al., 1999). Thus, weeds are responsible for significantly reducing the agricultural production (Silva et al., 2009).

Among the weeds are invasive exotic species, that is, non-native plants with the capacity to invade and impact natural and anthropogenic ecosystems. Although there is a vast literature on weeds, little is known about the contribution of invasive exotic species in this universe, as well as nothing is known about the influence of bovine manure on the dissemination of these species. In view of these issues and knowing that invasive exotic species are one of the main causes of global biodiversity loss (Williamson, 1996; Pagad et al., 2018), the objective of the present study was to evaluate the seed bank present in bovine manure used by farmers in the municipality of Itabaiana, SE.

\section{Methodology}

\subsection{Study Areas}

The present study was carried out in the rural area of the municipality of Itabaiana, SE (Figure 1), which has the As' climate (tropical with dry and moderate summer and rainy winter) according to the Köppen-Geiger classification (Tenório et al., 2009). This region has a separation varying between 1,100 and 1,300 mm per year (Dantas and Ribeiro, 2010), with evapotranspiration of $800 \mathrm{~mm}$ (Vicente, 1999). The region is characterized as a transition region between Caatinga and Atlantic Forest (Dantas et al., 2010). The predominant soil is the Planossolo Solódico Eutrófico type (Jacomine et at., 1975). 
Figure 1: Rural properties in the municipality of Itabaiana, SE, where bovine manure samples were collected.

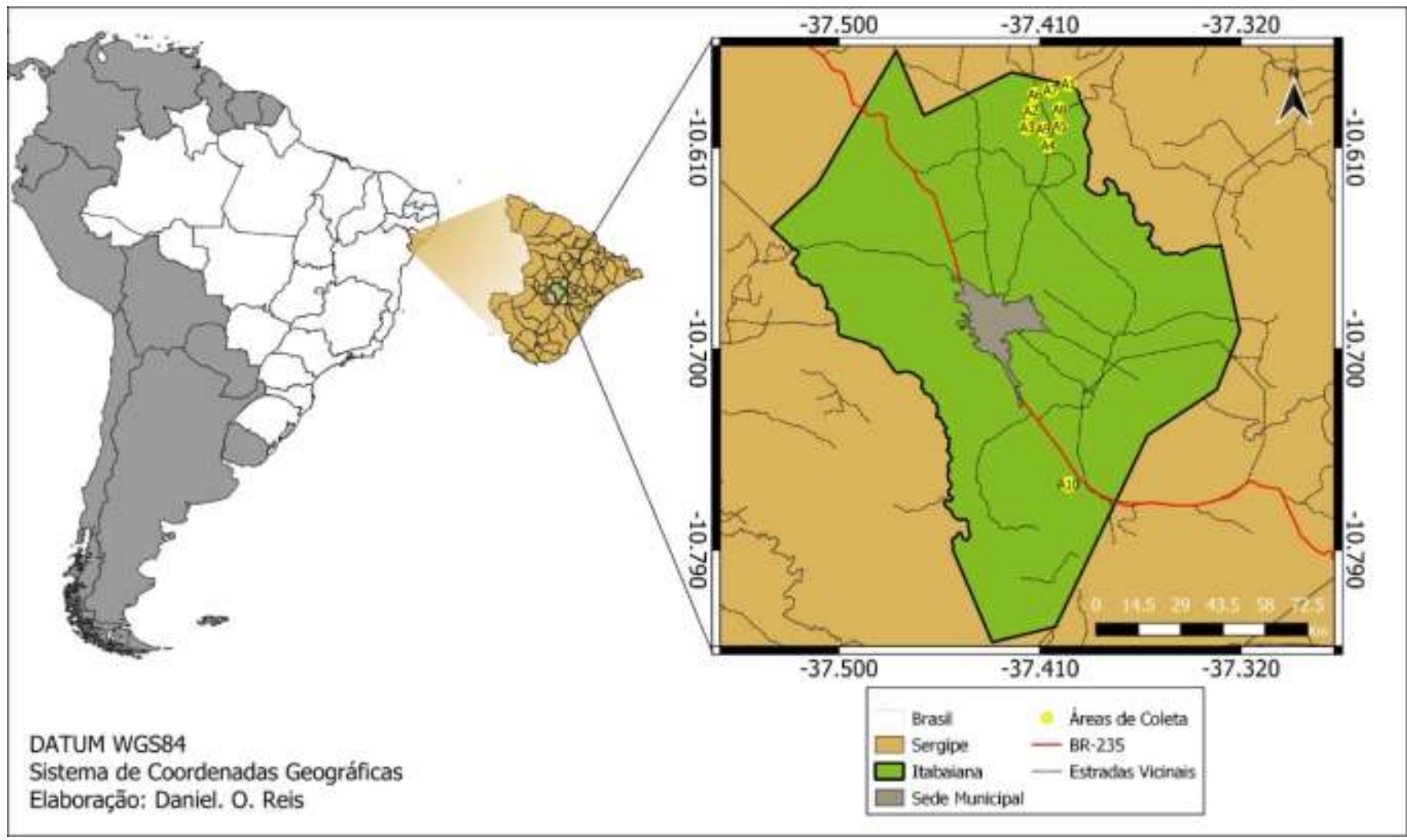

Source: Authors.

\subsection{Data Collection and Analysis}

Three $200 \mathrm{ml}$ samples of bovine manure were collected in 10 rural properties in the municipality of Itabaiana, SE. The samples were mixed in washed sand previously sterilized in an autoclave and later placed in aluminum trays. The trays were isolated in a greenhouse surrounded by fine mesh sombrite (30\%) for 90 days, with daily irrigation. In order to know the origin of bovine manure, structured interviews were conducted with the owners of the rural units where the manure samples were collected. These interviews sought to establish a relationship of place of origin of the manure with weeds observed in the experiment.

Evaluation of seed bank was performed by the accounting of emerged seedlings (Santos et al., 2010). The identification of the species was carried out by consulting the specialized literature and the control material deposited in herbariums. All species were collected, herborized and deposited at the Herbarium ASE of the Federal University of Sergipe, São Cristóvão, SE. The taxonomic classification was prepared according to the APG IV System (2016) and the spelling of the names of the authors of the species according to Flora do Brasil 2020 (2021).

Having the species list, they were classified according to their origin in native and non-native. The categorization was performed by consulting the specialized literature (Bionet-eafrinet, 2021; Cabi, 2021; I3N / Brasil, 2021; ISSG, 2021).

For each species were calculated absolute and relative values of density, frequency and importance value, the latter being obtained by summation of the densities and relative frequencies (Fabricante et al., 2016). The diversity of the seed bank was assessed using the Shannon-Weaver index (H ') (Shannon and Weaver, 1949) and evenness through the evenness index (Pitelou, 1977). The statistical analysis was performed using the software Past 2:17 (C) (Hammer et al., 2001) and formulas in Excel spreadsheet. 


\section{Results}

35 species belonging to 28 genera and 17 botanical families were inventoried. The most abundant families were Poaceae with nine (25.71\%) species, Asteraceae and Amaranthaceae with four (11.43\%) each one, Cyperaceae with three $(8.57 \%)$ and Euphorbiaceae and Rubiaceae with two (5.71\%). The other families presented only one species (2.86\%) each (Table 1).

Table 1. List of native $(\mathrm{N})$ and non-native $(\mathrm{NN})$ species inventoried in the bovine manure seed bank in Itabaiana, SE.

\begin{tabular}{|c|c|c|}
\hline Family & Species & Status \\
\hline \multirow{4}{*}{ Amaranthaceae } & Alternanthera tenella Colla & $\mathrm{N}$ \\
\hline & Amaranthus blitum L. & $\mathrm{NN}$ \\
\hline & Amaranthus spinosus $\mathrm{L}$. & $\mathrm{N}$ \\
\hline & Amaranthus viridis $\mathrm{L}$. & NN \\
\hline \multirow[t]{4}{*}{ Asteraceae } & Ageratum conyzoides $\mathrm{L}$. & $\mathrm{N}$ \\
\hline & Eclipta prostrata (L.) L. & $\mathrm{N}$ \\
\hline & Emilia fosbergii Nicolson & $\mathrm{N}$ \\
\hline & Emilia sonchifolia (L.) DC. ex Wight & $\mathrm{N}$ \\
\hline Commelinaceae & Murdannia nudiflora (L.) Brenan & $\mathrm{N}$ \\
\hline Cucurbitaceae & Cucurbita sp. & $\mathrm{NN}$ \\
\hline \multirow[t]{3}{*}{ Cyperaceae } & Cyperus iria $\mathrm{L}$. & $\mathrm{N}$ \\
\hline & Cyperus surinamensis Rottb. & $\mathrm{N}$ \\
\hline & Eleocharis sp. & $\mathrm{N}$ \\
\hline \multirow[t]{2}{*}{ Euphorbiaceae } & Euphorbia hirta L. & $\mathrm{N}$ \\
\hline & Euphorbia hyssopifolia $\mathrm{L}$. & $\mathrm{N}$ \\
\hline Fabaceae & Senna obtusifolia (L.) H.S.Irwin \& Barneby & $\mathrm{N}$ \\
\hline Lamiaceae & Eplingiella fruticosa (Salzm. ex Benth.) Harley \& J.F.B. Pastore & $\mathrm{N}$ \\
\hline Lythraceae & Cuphea sp. & $\mathrm{N}$ \\
\hline Malvaceae & Sida spinosa $\mathrm{L}$. & $\mathrm{N}$ \\
\hline Molluginaceae & Mollugo verticillata $\mathrm{L}$. & $\mathrm{N}$ \\
\hline Onagraceae & Ludwigia erecta (L.) H.Hara & $\mathrm{N}$ \\
\hline Phyllanthaceae & Phyllanthus tenellus Roxb. & $\mathrm{N}$ \\
\hline Plantaginaceae & Scoparia dulcis $\mathrm{L}$. & $\mathrm{N}$ \\
\hline \multirow[t]{9}{*}{ Poaceae } & Axonopus compressus (Sw.) P. Beauv. & $\mathrm{N}$ \\
\hline & Chloris barbata $\mathrm{Sw}$. & $\mathrm{N}$ \\
\hline & Dactyloctenium aegyptium (L.) Willd. & $\mathrm{NN}$ \\
\hline & Digitaria insularis (L.) Fedde & $\mathrm{N}$ \\
\hline & Eleusine indica (L.) Gaertn. & $\mathrm{NN}$ \\
\hline & Eragrostis maypurensis (Kunth) Steud. & $\mathrm{N}$ \\
\hline & Eragrostis tenella (L.) P.Beauv. ex Roem. \& Schult. & $\mathrm{NN}$ \\
\hline & Melinis repens (Willd.) Zizka & NN \\
\hline & Sporobolus sp. & $\mathrm{N}$ \\
\hline \multirow[t]{2}{*}{ Rubiaceae } & Borreria capitata (Ruiz \& Pav.) DC. & $\mathrm{N}$ \\
\hline & Oldenlandia corymbosa $\mathrm{L}$. & $\mathrm{N}$ \\
\hline Solanaceae & Solanum americanum Mill. & $\mathrm{N}$ \\
\hline
\end{tabular}


The species with the highest importance value was Euphorbia hirta because it has the highest density $(\mathrm{AD}=1122$ ind $\left.\mathrm{m}^{2} ; \mathrm{RD}=62.07 \%\right)$ and was present in $28(\mathrm{AF}=93.33 \%$; $\mathrm{RF}=13.93 \%)$ sample units. The second species with the highest importance value was Emilia sonchifola for presenting the second highest density $\left(\mathrm{AD}=223.4 \mathrm{~m}^{2} ; \mathrm{RD}=12.35 \%\right)$ and being present in all samples $(\mathrm{AF}=100 \% ; \mathrm{RF}=14,93 \%)$. On the other hand, the third species with the highest importance value was Eleusine indica for having the third highest density $\left(\mathrm{AD}=171.2 \mathrm{~m}^{2} ; \mathrm{RD}=9.46 \%\right)$ and being present in $21(\mathrm{AF}=70 \%$; $\mathrm{R}=10$, $45 \%$ ) sample units (Table 2).

Table 2. Species of the seed bank in bovine manure in Itabaiana-SE and their respective structural parameters. Where: NI = number of individuals; $\mathrm{AD}=$ absolute density; $\mathrm{RD}=$ relative density $; \mathrm{AF}=$ absolute frequency; $\mathrm{RF}=$ relative frequency; $\mathrm{VI}=$ value of importance.

\begin{tabular}{|c|c|c|c|c|c|c|}
\hline Species & NI & $\mathrm{AD}$ & $\mathrm{RD}$ & $\mathrm{AF}$ & $\mathrm{RF}$ & VI \\
\hline Euphorbia hirta & 990 & 1122 & 62.07 & 93.33 & 13.93 & 76 \\
\hline Emilia sonchifola & 197 & 223.4 & 12.35 & 100 & 14.93 & 27.28 \\
\hline Eleusine indica & 151 & 171.2 & 9.467 & 70 & 10.45 & 19.91 \\
\hline Euphorbia hyssopifolia & 67 & 75.96 & 4.201 & 70 & 10.45 & 14.65 \\
\hline Scoparia dulcis & 15 & 17.01 & 0.94 & 33.33 & 4.975 & 5.916 \\
\hline Phyllanthus tenellus & 10 & 11.34 & 0.627 & 33.33 & 4.975 & 5.602 \\
\hline Cyperus surinamensis & 57 & 64.63 & 3.574 & 13.33 & 1.99 & 5.564 \\
\hline Amaranthus viridis & 17 & 19.27 & 1.066 & 30 & 4.478 & 5.543 \\
\hline Solanum americanum & 9 & 10.2 & 0.564 & 23.33 & 3.483 & 4.047 \\
\hline Sporobolus sp. & 12 & 13.61 & 0.752 & 20 & 2.985 & 3.737 \\
\hline Alternanthera tenella & 8 & 9.07 & 0.502 & 20 & 2.985 & 3.487 \\
\hline Dactyloctenium aegyptium & 8 & 9.07 & 0.502 & 16.67 & 2.488 & 2.989 \\
\hline Chloris barbata & 5 & 5.669 & 0.313 & 16.67 & 2.488 & 2.801 \\
\hline Sida spinosa & 9 & 10.2 & 0.564 & 13.33 & 1.99 & 2.554 \\
\hline Amaranthus blitum & 5 & 5.669 & 0.313 & 13.33 & 1.99 & 2.304 \\
\hline Murdannia nudiflora & 4 & 4.535 & 0.251 & 10 & 1.493 & 1.743 \\
\hline Digitaria insularis & 3 & 3.401 & 0.188 & 10 & 1.493 & 1.681 \\
\hline Eleocharis sp. & 4 & 4.535 & 0.251 & 6.667 & 0.995 & 1.246 \\
\hline Mollugo verticillata & 2 & 2.268 & 0.125 & 6.667 & 0.995 & 1.12 \\
\hline Eragrostis maypurensis. & 2 & 2.268 & 0.125 & 6.667 & 0.995 & 1.12 \\
\hline Eclipta prostrata & 2 & 2.268 & 0.125 & 6.667 & 0.995 & 1.12 \\
\hline Senna obtusifolia & 2 & 2.268 & 0.125 & 6.667 & 0.995 & 1.12 \\
\hline Melinis repens & 2 & 2.268 & 0.125 & 6.667 & 0.995 & 1.12 \\
\hline Ageratum conyzoides & 2 & 2.268 & 0.125 & 6.667 & 0.995 & 1.12 \\
\hline Axonopus compressus & 2 & 2.268 & 0.125 & 3.333 & 0.498 & 0.623 \\
\hline Amaranthus spinosus & 1 & 1.134 & 0.063 & 3.333 & 0.498 & 0.56 \\
\hline Eragrostis tenella & 1 & 1.134 & 0.063 & 3.333 & 0.498 & 0.56 \\
\hline Cyperus iria & 1 & 1.134 & 0.063 & 3.333 & 0.498 & 0.56 \\
\hline Cucurbita sp. & 1 & 1.134 & 0.063 & 3.333 & 0.498 & 0.56 \\
\hline Borreria capitata & 1 & 1.134 & 0.063 & 3.333 & 0.498 & 0.56 \\
\hline Oldenlandia corymbosa & 1 & 1.134 & 0.063 & 3.333 & 0.498 & 0.56 \\
\hline Ludwigia erecta & 1 & 1.134 & 0.063 & 3.333 & 0.498 & 0.56 \\
\hline Emilia fosbergii & 1 & 1.134 & 0.063 & 3.333 & 0.498 & 0.56 \\
\hline
\end{tabular}




\begin{tabular}{lcccccc} 
Eplingiella fruticosa & 1 & 1.134 & 0.063 & 3.333 & 0.498 & 0.56 \\
Cuphea sp. & 1 & 1.134 & 0.063 & 3.333 & 0.498 & 0.56 \\
\hline Total & 1595 & 1808 & 100 & 670 & 100 & 200 \\
\hline
\end{tabular}

Source: Authors.

Joined, the non-native species (Dactyloctenium aegyptium, Eleusine indica, Melinis repens, Eragrostis tenella, Amaranthus viridis, Amaranthus blitum and Cucurbita sp.) reported an absolute density of 209.75 ind. $\mathrm{m}^{2}(\mathrm{RD}=11.6 \%)$ and one absolute frequency of $143.33 \%(\mathrm{RF}=21.4 \%)$. The importance value was $33(\mathrm{VI}=16.5 \%)$. Despite the amount of species not be so high, it is important to note that all non native sampled cause many environmental and economic impacts.

\section{Discussion}

From the reviewed studies, some had lower number of species compared to this study: In Balsas, MA, seven species were sampled (Diniz et al, 2017.); in Morrinhos, GO, 26 species (Ferreira, 2017); in Viana, MA, 12 (Corrêa et al., 2018) and in São Luís, MA, 13 (Silva et al., 2018). However, other studies showed a higher number: in Vargem Bonita, DF, there were 39 species (Carmona, 1995); in Ponta Grossa, PR, 49 species (Deiss et al., 2018) and; in São Luís Gonzaga, MA, 55 (Mesquita et al., 2016). Differences in the sampling effort, between the biome / ecosystem studied and in the methods of collecting soils and data, should explain the divergences between the results of the compared studies.

The families Poaceae, Asteraceae and Amaranthaceae were also quite representative in other studies, such as those developed by Ferreira (2017), Deiss et al. (2018) and Diniz et al. (2017). Many species of these families exhibit characteristics which favor these results, such as the production of large quantities of seeds and the dispersion in different environments (Lorenzi, 2006; Holm et al, 1977; And Pedrotti Guarim-Neto, 1998).

Some of the non-native species found in the present study (Eleusine indica and Melinis repens) are species intentionally introduced for pasture formation (Pastore et al., 2012; Fabricante, 2013; Fabricante, 2014). Others, however, were introduced accidentally (Amaranthus viridis, Amaranthus blitum, Dactyloctenium aegyptium and Eragrostis tenella) or were brought here for other reasons (feeding: Cucurbita sp.) and started to invade agricultural areas and pastures.

The presence of several non-native plants occurring together in bovine manure can corroborate to the hypotheses of facilitation (Bruno et al., 2003) and invasive meltdown (Simberloff and Von Holle, 1999; Simberloff, 2006), where the nonnative species may be facilitating the arrival and establishment of new non-native species through changes in the natural conditions of the environment. More studies are needed to better understand this situation.

The diversity and evenness of the seed bank was 1.485 and 0.42 , respectively. These values were different from those obtained by Jakelaitis et al. (2014), Mesquita et al. (2016), Cardoso et al. (2016) and Ferreira (2017), as well as the structural parameters also differed from those found in the consulted studies (Diniz et al., 2017; Ferreira, 2017; Corrêa et al., 2018; Silva et al., 2018; Carmona, 1995; Deiss et al., 2018; Mesquita et al., 2016).

All the divergences pointed out throughout the text must be the result of the selection of species that the animals make when feeding and the ability of the seeds to pass unharmed through their digestive tract. According to Deminicis et al. (2009), the passage of seeds through the digestive tract of cattle influences the composition and abundance of seeds.

Originally from Africa, Dactyloctenium aegyptium is popularly known as chicken-foot grass, parrot-grass and frog-hand grass. It competes with agricultural crops, decreases the quality of pastures, it is a host of crop diseases and has allelopathic potential (Fabricante, 2014). In Brazil it is distributed in all regions: North (Amapá, Pará, Roraima, Tocantins), Northeast (Alagoas, Bahia, Ceará, Maranhão, Paraíba, Pernambuco, Piauí, Rio Grande do Norte, Sergipe), Midwest (Goiás, Mato Grosso do 
Sul, Mato Grosso), Southeast (Espírito Santo, Minas Gerais, Rio de Janeiro, São Paulo), South (Rio Grande do Sul, Santa Catarina) (Flora do Brasil 2020, 2021).

The species Eragrostis tenella, also has the African continent as its origin. This species has the same impacts as the previous one (Fabricante, 2013) and occurs in the same regions: North (Amazonas, Amapá, Pará, Roraima), Northeast (Alagoas, Bahia, Ceará, Maranhão, Paraíba, Pernambuco, Piauí, Rio Grande do Norte, Sergipe), Midwest (Federal District, Goiás, Mato Grosso do Sul, Mato Grosso), Southeast (Espírito Santo, Minas Gerais, Rio de Janeiro, São Paulo) and South (Paraná) (Flora do Brasil 2020, 2021).

With the vernacular names of favorite grass, grasshopper grass, pink grass and christmas grass, Melinis repens is also an African species. It causes impacts to agricultural systems (Fabricante, 2013), facilitates fires (CABI, 2021) and occurs in the Northeast (Alagoas, Bahia, Ceará, Paraíba, Pernambuco, Piauí, Rio Grande do Norte, Sergipe), Midwest (District Federal, Goiás, Mato Grosso do Sul, Mato Grosso), Southeast (Espírito Santo, Minas Gerais, Rio de Janeiro, São Paulo) and South (Paraná, Rio Grande do Sul, Santa Catarina) (Flora do Brasil 2020, 2021).

The caruru or bredo, as it is popularly called Amaranthus viridis species, is originally from Central America. It is an allelopathic species that affects the resilience of invaded sites, is toxic to animals and impacts agriculture (Fabricante, 2013). There are records of occurrence of the species in all regions of Brazil: North (Amazonas, Pará), Northeast (Bahia, Ceará, Maranhão, Paraíba, Pernambuco, Piauí, Rio Grande do Norte, Sergipe), Midwest (Distrito Federal, Goiás, Mato Grosso do Sul, Mato Grosso), Southeast (Minas Gerais, Rio de Janeiro, São Paulo) and South (Paraná, Rio Grande do Sul, Santa Catarina) (Flora do Brasil 2020, 2021).

The species Eleusine indica, vernaculously known as chicken-grass is an Asian plant with the capacity to affect agricultural crops (Corrêa, et al., 2016) and is host of agricultural pests (Belle et al., 2017). There is a confirmed occurrence in the North (Acre, Amazonas, Amapá, Pará, Rondônia, Roraima, Tocantins), Northeast (Alagoas, Bahia, Ceará, Maranhão, Paraíba, Pernambuco, Piauí, Rio Grande do Norte, Sergipe), Midwest (District Federal, Goiás, Mato Grosso do Sul, Mato Grosso), Southeast (Espírito Santo, Minas Gerais, Rio de Janeiro, São Paulo) and South (Paraná, Rio Grande do Sul, Santa Catarina) (Flora do Brasil 2020, 2021).

On the other hand, Amaranthus blitum species is commonly known as pigweed-sheet-of-gourd and is originally from Europe (Schneider, 2007). Like other species, it affects agricultural crops (Macedo, et al., 2003). It has distribution in the Northeast (Pernambuco and Sergipe) and South (Paraná, Rio Grande do Sul, Santa Catarina) (Flora do Brasil 2020, 2021).

Through interviews carried out with farmers, it was found that the manure used in this study is originated in the municipalities of Monte Alegre, Nossa Senhora Aparecida, Nossa Senhora da Glória, Poço Redondo and Poço Verde in Sergipe. All of them are in the Caatinga domains, which justifies the presence of some typical species of this vegetation, such as Axonopus compressus and Murdannia nudiflora.

\section{Conclusion}

The results obtained demonstrate that bovine manure has a high wealth of weeds, which is quite worrying, as they are species that cause damage to Brazilian agriculture. In addition, there are several non-native species that have substantial impacts on natural ecosystems.

\section{References}

APG (Angioperm Phylogeny Group). (2016). An update of the Angiosperm Phylogeny Group classification for the orders and families of flowering plants: APG IV. Botanical Journal of the Linnean Society, 181, 1-20.

Barros, E., Pashanasi, B., Constantino, R., \& Lavelle, P. (2002). Effects of land-use system on the soil macrofauna in western Brazilian Amazonia. Biology and Fertility of Soils, 35(5), 338-347. 10.1007/s00374-002-0479-z 
Belle, C., Kulczynski, S. M., Kaspary, T. E., \& Kuhn, P. R. (2017). Plantas daninhas como hospedeiras alternativas para Meloidogyne incognita. Nematropica, 47(1), 26-33. Retrivied from https://journals.flvc.org/nematropica/article/view/105055

Bionet-Eafrinet. (2021). Invasive Species. https://keys.lucidcentral.org/keys/v3/eafrinet/

Brasil, E. C., Viégas, I., Silva, E. S. A., \& Gato, R. F. (1999). Nutrição e adubação: conceitos e aplicações na formação de mudas de pimenta longa. Embrapa Amazônia Oriental-Documentos (INFOTECA-E). https://www.infoteca.cnptia.embrapa.br/bitstream/doc/377441/1/OrientalDoc13.pdf

Brighenti, A., Lamego, F., de Miranda, J. E. C., de Oliveira, V. M., \& Oliveira, P. D. (2017). Plantas Tóxicas em Pastagens:(Senecio brasiliensis e S. madagascariensis)-Família: Asteraceae. Embrapa Gado de Leite-Comunicado Técnico (INFOTECA-E). Retrivied From https://www.infoteca.cnptia.embrapa.br/infoteca/handle/doc/1083486

Bruno, J. F., Stachowicz, J. J., \& Bertness, M. D. (2003). Inclusion of facilitation into ecological theory. Trends in ecology \& evolution, 18(3), 119-125. $10.1016 /$ S0169-5347(02)00045-9

CABI. (2021). Invasive Species Compendium. https://www.cabi.org/isc/

Cardoso, I. S., Soares, M. P., Araujo, V. T., Cabral, P. H. R., Jakelaitis, A., \& Madalao, J. C. (2016). Bank of weed seeds in agrosystems in the brazilian cerrado. Planta Daninha, 34(3), 443-451. 10.1590/s0100-83582016340300005

Carmona, R. (1995). Banco de sementes e estabelecimento de plantas daninhas em agroecossistemas. Planta daninha, 13(1), 3-9. 10.1590/S010083581995000100001 .

Chase, M. W., Christenhusz, M. J. M., Fay, M. F., Byng, J. W., Judd, W. S., Soltis, D. E., . \& Stevens, P. F. (2016). An update of the Angiosperm Phylogeny Group classification for the orders and families of flowering plants: APG IV. Botanical Journal of the Linnean Society, 181(1), 1-20. 10.1111/boj.12385

Corrêa, M. J., Moreira, R. C., Pinheiro, J., Dias, B. R., \& Marinho, T. R. (2018). Fluxo de emergência do banco de sementes de plantas espontâneas na cultura do arroz no Maranhão. Cadernos de Agroecologia, 13(1). Retrivied from http://cadernos.aba-agroecologia.org.br/index.php/cadernos/article/download/1065/598

Corrêa, M. J. P., Alves, G. L., Rocha, L. G. F., \& Silva, M. R. M. (2015). Períodos de interferência de plantas daninhas na cultura do feijão caupi. Revista de Ciências Agroambientais, 13(2). 10.5327/rcaa.v13i2.1183

Cremonez, F. E., Cremonez, P. A., de Camargo, M. P., \& Feiden, A. (2013). Principais plantas com potencial alelopático encontradas nos sistemas agrícolas brasileiros. Acta Iguazu, 2(5), 70-88. doi :10.48075/actaiguaz.v2i5.9183

Dantas, T. V. P., \& Ribeiro, A. D. S. (2010). Caracterização da vegetação do Parque Nacional Serra de Itabaiana, Sergipe-Brasil. Biotemas, $23(4)$, 9-18. $10.5007 / 2175-7925.2010 \mathrm{v} 23 \mathrm{n} 4 \mathrm{p} 9$.

Dantas, T. V. P., \& Ribeiro, A. D. S. (2010). Florística e estrutura da vegetação arbustivo-arbórea das Areias Brancas do Parque Nacional Serra de Itabaiana/Sergipe, Brasil. Brazilian Journal of Botany, 33(4), 575-588. 10.1590/S0100-84042010000400006

Deiss, L., Moraes, A., Pelissari, A., Porfírio-Da-Silva, V., \& Schuster, M. Z. (2018). Weed seed bank in an agroforestry system with eucalyptus in Subtropical Brazil. Planta Daninha, 36. 10.1590/s0100-83582018360100022

Deminicis, B. B., Almeida, J. C. C., Malafaia, P. A. M., Blume, M. C., Abreu, J. B. R., \& Vieira, H. D. (2009). Germinação de sementes em placas fecais bovinas. Archivos de zootecnia, 58(221), 73-84. https://scielo.isciii.es/pdf/azoo/v58n221/art8.pdf

Diniz, K. D., Macedo, N. C., de França Portela, G., \& Rezende, L. P. (2017). Banco de sementes de plantas daninhas em área de pastagem Panicum maximum Jacq. cultivar Mombaça no município de Balsas-MA. Biodiversidade, 16(3). https://periodicoscientificos.ufmt.br/ojs/index.php/biodiversidade/article/view/6011

Jacomine, P. K. T., Montenegro, J. O., Ribeiro, M. R., \& Formiga, R. A. (1975). Levantamento exploratório-reconhecimento de solos do Estado de Sergipe. Embrapa Solos-Séries anteriores (INFOTECA-E). Retrivied from https://www.infoteca.cnptia.embrapa.br/infoteca/handle/doc/331179

EMBRAPA. (2021) . Adubos e corretivos. http://www.agencia.cnptia.embrapa.br/gestor/tomate/arvore/CONT000fa2qor2v02wx5eo01xezls9xq8p5g.html

Fabricante, J. R., Araújo, K. C., Castro, R. A., \& Cotarelli, V. M. (2016). Banco de sementes do solo de sítios de Caatinga sob influência do Projeto de Integração do Rio São Francisco. Scientia Plena, 12(4). 10.14808/sci.plena.2016.041001

Fabricante, J. R. (2014). Plantas Exóticas e Exóticas Invasoras da Caatinga-Vol. 4. Bookess.

Fabricante, J. R. Plantas Exóticas e Exóticas Invasoras da Caatinga-Vol. 3. Bookess.

Fabricante, J. R. Plantas Exóticas e Exóticas Invasoras da Caatinga-Vol. 1. Bookess.

Ferreira, P. R. N. (2017). Banco de sementes de plantas daninhas em sucessão de culturas nos sistemas irrigado e sequeiro. Dissertação (Mestrado) - Instituto Federal de Educação, Ciências e Tecnologia Goiano, Morrinhos.

Finatto, J., Altmayer, T., Martini, M. C., Rodrigues, M., Basso, V., \& Hoehne, L. (2013). A importância da utilização da adubação orgânica na agricultura. Revista destaques acadêmicos, 5(4). http://univates.br/revistas/index.php/destaques/article/view/327

Hammer, Ø., Harper, D. A., \& Ryan, P. D. (2001). PAST: Paleontological statistics software package for education and data analysis. Palaeontologia electronica, 4(1), 9. https://paleo.carleton.ca/2001_1/past/past.pdf

Holm, L. G., Plucknett, D. L., Pancho, J. V., \& Herberger, J. P. (1977). The World's Worst Weeds. The world's worst weeds. 
I3N/BRASIL. (2021) . Base de dados I3N Brasil de espécies exóticas invasoras. http://bd.institutohorus.org.br/www/

ISSG. Global Invasive Species Database. (2021). http://issg.org/database/welcome/aboutGISD.asp

Flora do Brasil 2020. (2021). http://floradobrasil.jbrj.gov.br

Lorenzi, H. (2006). Manual de identificação de plantas daninhas: plantio direto e convencional. Nova Odessa: Plantarum.

Jakelaitis, A., Cardoso, I. S., \& Soares, M. P. (2014). Banco de sementes de plantas daninhas em solos cultivados com culturas e pastagens-10.14688/19843801/gst. v7n2p63-73. Global Science and Technology, 7(2). https://www.scielo.br/j/pd/a/fBqgY83SLfNzszzSmbSfhCM/abstract/?lang=pt

Mascarenhas, R. E., Modesto Júnior, M. D. S., Dutra, S., Souza Filho, A. P. D. S., \& Teixeira Neto, J. F. (1999). Plantas daninhas de uma pastagem cultivada de baixa produtividade no nordeste paraense. Planta daninha, 17(3), 399-418. 10.1590/S0100-83581999000300008

Macedo, J. F., Brandão, M., \& Lara, J. F. R. (2003). Plantas daninhas na pós-colheita de milho nas várzeas do rio São Francisco, em Minas Gerais. Planta daninha, 21(2), 239-248. 10.1590/S0100-83582003000200009

Mesquita, M. L. R., Andrade, L. A., \& Pereira, W. E. (2016). Germination, floristic composition and phytosociology of the weed seed bank in rice interropped with corn fields. Revista Brasileira de Ciências Agrárias, 11(1), 14-20. Retrivied from https://www.redalyc.org/pdf/1190/119045655003.pdf

Pagad, S., Genovesi, P., Carnevali, L., Schigel, D., \& McGeoch, M. A. (2018). Introducing the global register of introduced and invasive species. Scientific Data, 5(1), 1-12. 10.1038/sdata.2017.202

Pastore, M., Rodrigues, R. S., Simão-Bianchini, R., \& Filgueiras, T. S. (2012). Guia de Campo: Plantas Exóticas Invasoras na Reserva Biológica do Alto da Serra de Paranapiacaba, Santo André-SP.

Pedrotti, D. E., \& Guarim Neto, G. (1998). Flora ruderal da cidade de Cuiabá, Mato Grosso, Brasil. Acta bot. bras, 135-143. 10.1590/S0102-33061998000200004

Pielou, U. C. (1977). Mathematical diversity. John Wiley e Sons.

Pitelli, R. A. (1987). Competição e controle das plantas daninhas em áreas agrícolas. Série técnica IPEF, 4(12), 1-24. http://www.lpv.esalq.usp.br/sites/default/files/8\%20-\%20Leitura\%20interferencia\%20das\%20plantas\%20daninhas\%202_0.pdf

Pitelli, R. A. (2015). O termo planta-daninha. Planta Daninha, 33(3), 622-623. 10.1590/S0100-83582015000300025

Santos, D. M., da Silva, K. A., dos Santos, J. M. F. F., Lopes, C. G. R., Mendonça P. R. M., \& Lima A. E. (2010). Variação espaço-temporal do banco de sementes em uma área de Floresta Tropical Seca (Caatinga)-Pernambuco. Revista de Geografia (Recife), 27(1), $234-253$.

Schneider, A. A. (2007). A flora naturalizada no estado do Rio Grande do Sul, Brasil: herbáceas subespontâneas. Biociências, 15(2). 257-268. http://www.institutocaminhosoriente.com/Livros/A\%20Flora\%20no\%20RS.pdf

Shannon, C. E., \& Weaver, W. (1949). The mathematical theory of information. Urbana: University of Illinois Press, 97.

Silva, I. A. B., Kuva, M. A., Alves, P. L. C. A., \& Salgado, T. P. (2009). Interferência de uma comunidade de plantas daninhas com predominância de Ipomoea hederifolia na cana-soca. Planta daninha, 27(2), 265-272. 10.1590/S0100-83582009000200008

Silva, M. R. M., Peixoto, M. C. R., Santos, R. N. V., Cardoso, M. P., \& Pires, H. P. (2018). Banco de sementes de plantas espontâneas após cultivo do milho sob cobertura de palha de babaçu. Cadernos de Agroecologia, 13(1).

Simberloff, D. (2006). Invasional meltdown 6 years later: important phenomenon, unfortunate metaphor, or both? Ecology Letters, 9(8), 912-919. 10.1111/j.14610248.2006.00939.x

Simberloff, D., \& Von Holle, B. (1999). Positive interactions of nonindigenous species: invasional meltdown? Biological invasions, 1(1), 21-32. 10.1023/A:1010086329619

Tenório, J. C. G.; Bezerra, M. F. A.; Costa, A. A. A.; Bezerra, A. C. C.; CavalcantI, L. H. (2009) Mixobiota do Parque Nacional Serra de Itabaiana, SE, Brasil: Stemonitales. Acta Botanica Brasilica, 3(23), 644-656.

de Menezes Trigueiro, R., \& Guerrini, I. A. (2003). Uso de biossólido como substrate para produção de mudas de eucalipto. Scientia Forestalis/Forest Sciences, 150-162. http://hdl.handle.net/11449/67553

Vicente, A. Levantamento florístico de um fragmento florestal na Serra de Itabaiana-Sergipe. (1999). Tese de Doutorado. Dissertação de mestrado, Universidade Federal Rural de Pernambuco.

Williamson, M. H., \& Fitter, A. (1996). The characters of successful invaders. Biological conservation, 78(1-2), 163-170. 1016/0006-3207(96)00025-0 